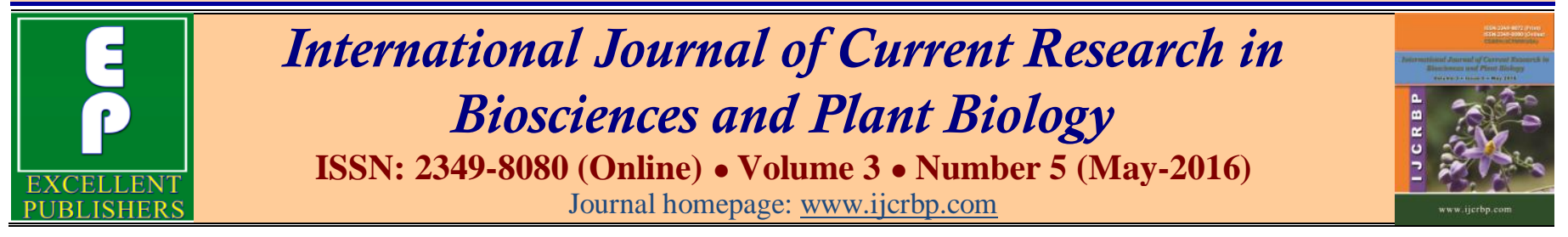

Original Research Article

doi: http://dx.doi.org/10.20546/ijcrbp.2016.305.019

\title{
Ethnobotany in Relation to Health Security in District Bastar of Chhattisgarh State, India
}

\author{
Mithlesh Kumar Sinha ${ }^{* *}$, V. K. Kanungo² and M. L. Naik3 \\ ${ }^{1}$ Department of Botany, Government N.P.G. College of Science, Raipur, Chhattisgarh, India \\ ${ }^{2}$ Department of Botany, Government Nagarjuna P.G. College of Science, Raipur (C.G.), Chhattisgarh, India \\ 3 Professor and Head (Retired), SOS. in Life Science, Pt. Ravi Shankar Shukla University Raipur (C.G.), Chhattisgarh, India
}

*Corresponding author.

\begin{abstract}
A bstract
In present study ethnobotany in relation to health security was investigated in 20 villages of Bastar district. Information regarding the plants used as a medicine was collected by gathering information with the help of questionnaire and by conducting personal interview with the knowledgeable person of the villages. Four hundred tribals (twenty from each village) were selected for the collection of information through interview. The name of medicinal plant, vernacular name and its method of use against the disease were noted by making dialect in their own language. In present study documentation of 118 plants belonging to 47 families were given by the tribals of the village regarding the use against 39 types of health ailments. All the five prominent tribals of the Bastar had a great similarity regarding the use of plants as a medicine; difference was occurred in terms of drug preparation and its administration. This vital knowledge of tribal health security was documented.
\end{abstract}

\section{Introduction}

Chhattisgarh has a rich and varied flora due to its diversified topography and variable climatic condition. About 20-25 tribes are living in isolated or in combination in four different zones like Central, Eastern, Western, Northern and Southern zones respectively. The Gonds constitute the largest tribe amongst the other tribes of the state. District Bastar is located in the southern zone of Chhattisgarh. Gonds, Bhatara, Muriya, Mariya and Halba are the main tribes of Bastar and they have unique identification in the country. Bastar is a tribal district where about $70 \%$ of the total population is tribals and which constitutes $26.76 \%$ of the total tribal population of the Chhattisgarh state.

Forests are not only the source of major and minor forest products but it also provides and fulfils the basic needs and demands directly and indirectly in life pattern of tribals. They also use an enormous range of wild plants and have developed a unique understanding of the forest resources and passed on these traditions of medicinal remedies and knowledge by word of mouth from one generation to other generation. They also have the key to understanding, utilizing and conserving the plant resources. The storage of ethnobotanical traditional knowledge of plants and animals origin in memory is really a God gift for a resource person in each tribal group. Each tribal group has different ethnobotanical knowledge than its neighbors, which is either acculturated or lost with the knowledgeable person of that tribe.

The Traditional and primitive folk healing practices among tribals of Bastar normally involve medicine derived from plants and animals available within local 
agro climatic zones. Different studies have conducted by scientists on folk healing practices in different districts of Chhattisgarh. It is evident that folk-logic including cultural, biological, historical, religious, and environmental factors that significantly influence the folk therapy. The concepts of illness and healing are not universal. They vary from culture to culture. One third population of Chhattisgarh is tribal. They have their own value system and cultural interpretation of disease and treatment. They have a very different understanding of why people get sick, and how they can be treated. The Traditional healers of Bastar have been treating and rendering miraculous cure to thousands of patients annually. They claim to treat most complicated patients of bone fracture who have been refused by the hospitals in different cities. The ailments like infertility, cancer, malaria, diabetes, skin diseases are not beyond their expertise.

Plants knowledge amassed by experimentation over millennia and passed on orally from generation to generation (Schultes and Reis, 1995). One important current concern of ethnobotanical research is the potential use of plants as medicine, a knowledge that is often exclusive to the specific communities and linked to the local flora. As repeatedly emphasized in different contexts, the importance of plants in our lives, in addition to being a source of food, is their therapeutic potential; every culture in the world developed its own practices of treating the disease. The fund of knowledge developed over the millennia by thousands of ethnic groups, is largely unrecorded and faces the danger of becoming extinct. Our urgent concern is to preserve, refine and use this information for a more effective management of health.

The present investigation entitled "Ethnobotany in relation to health security of district Bastar of Chhattisgarh state" is the task to investigate the existing traditional knowledge of local tribal communities, forest villagers inhabiting in the areas of district Bastar of Chhattisgarh state.

\section{Materials and methods}

\section{Study area}

The district of Bastar is located in the southern part of Chhattisgarh state, situated at the height of $2000 \mathrm{M}$ above plateau MSL. In Chhattisgarh, state Bastar district is surrounded by Kanker district in the north Maharashtra state in the west Dantewada district in the south and
Orissa state in the east. The total forest area of the Bastar is $7112 \mathrm{sq} \mathrm{km}$, which is more than the $75 \%$ of total area of the district. Out of the total population, more than $70 \%$ are tribals like Gonds, Abujhmaria, Dardamaria, Muriya, Doriya, Dhruva, Bhatra, and Halba.

\section{Field study}

The present work involves various steps including field study in which questionnaire was filled by the tribal people and personal interview was organized, collection of plant specimen, preparation of herbarium and identification of plants with the help of flora was done. The study was conducted in the year 2006-2008. The methodology of the present work was adopted from some of the earlier workers like Jain, (1987, 1988), Masih, (1990) and Jain and Singh (1997). The methods of ethnobiological studies summarized by Roy (1989) were also consulted in the present study. The ethno-biological information was obtained from Baidyas, Sirhas, Gunias, knowledgeable person, experienced people, medicine men, and heads and local inhabitants of the village, who have knowledge of plants for health and livelihood security. Ethnobotanical survey in relation to health security was conducted in 20 villages of Bastar district and information was collected from 400 tribal people belonging to 8 different categories on the spot/ during the transit visit. The documentation of the information given by folk healers and Baidyas was documented under 10 headings. The Baidyas and folk healers of the area were interviewed individually for collection of information regarding the preparation of drug and its administration against diseases. Information was documented disease wise use of plant/plant parts for the preparation of drug. The cost of the treatment per episode/per disease was also noted.

\section{Results}

The In present study of ethno botany in relation to health security of Bastar district. Information regarding the plants used as a medicine was collected. Tribals have revealed an information of 118 plants belonging to 47 families of dicotyledons like Rutaceae, Combretaceae, Anacardiaceae, Labiatae, Malvaceae, Leguminosae, Myrtaceae, Moraceae, Asclepiadaceae, Apocynacae, Euphorbiaceae, Sterculiaceae, Solanaceae, Scrophulariaceae, Convolvulaceae, Amaranthaceae, Acanthaceae, Vitaceae, Oleaceae, Costaceae, Lythraceae, Plumbaginaceae, Meliaceae, Sapotaceae, Verbenaceae, Nyctaginaceae, Alangiaceae, Menispermaceae, Ebenaceae, Rubiaceae, Celastraceae, Hypoxidaceae, 
Rhamnaceae and 05 families of monocotyledons like Liliaceae, Zingiberaceae, Dioscoreaceae, Araceae and Poaceae (Table 1). These plants were used to treat 39 ailments by the local people.

Amongst the noted plants 37 were herbs, 27 were shrubs, 36 were trees, 17 were climbers and 1 was parasitic plant (Table 1 and Fig. 1). More than one part of the plant was found to be used as a medicine. The roots of 36 plants, stem of 14 plants, leaves of 40 plants, bark of 29 plants, seeds of 19 plants, fruits of 16 plants, flowers of 13 plants, rhizomes of 4 plants, fruit pulp of 4 plants, leaf pulp of 2 plants, and 22 whole plants were observed to be used as medicine (Table 1, Fig. 2). The medicine was prepared from different parts of the plants and used as a raw or in dry state or powder or mixture or liquid or in paste.

Table 1. Medicinal plants used by the tribals of district Bastar for health security, investigated during the year 2006-2008.

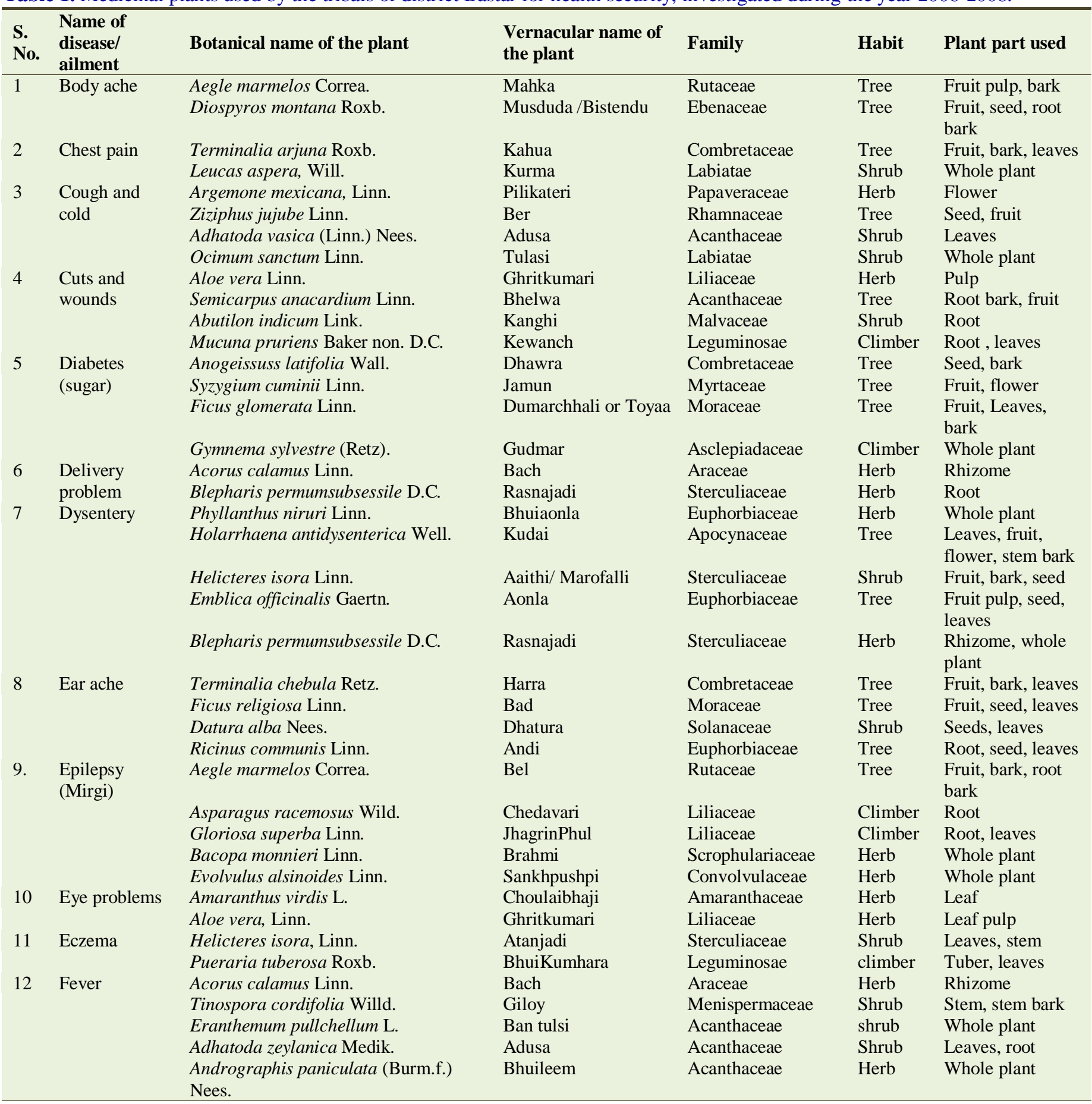




\begin{tabular}{|c|c|c|c|c|c|c|}
\hline $\begin{array}{l}\text { S. } \\
\text { No. }\end{array}$ & $\begin{array}{l}\text { Name of } \\
\text { disease/ } \\
\text { ailment }\end{array}$ & Botanical name of the plant & $\begin{array}{l}\text { Vernacular name of } \\
\text { the plant }\end{array}$ & Family & Habit & Plant part used \\
\hline \multirow[t]{3}{*}{13} & \multirow[t]{3}{*}{ Fracture } & Hemidesmus indicus (Linn.) Schult. & Anantmool & Asclepiadaceae & Shrub & Stem, leaves, root \\
\hline & & Cissus quardangularis (L.)Wall. & Hadjod & Vitaceae & Shrub & Stem \\
\hline & & Nyctanthes arbortristis Linn. & Harsinghar & Oleaceae & Shrub & Stem \\
\hline 14 & $\begin{array}{l}\text { Giddiness } \\
\text { (Murcha) }\end{array}$ & Ocimum basilicum Linn. & Tulsi & Lebiatae & Herb & Leaves, root, seed \\
\hline 15 & Head-ache & Costus speciosus Retz. & Keo-kand & Costaceae & Herb & Root \\
\hline \multirow[t]{3}{*}{16} & \multirow[t]{3}{*}{ Hydrocoel } & Curcuma amada Roxb. & JangaliHaldi & Zingiberaceae & Herb & Rhizome \\
\hline & & Semicarpus anacardium Linn. & Bhelva & Anacardiaceae & Tree & Root ,bark, seed \\
\hline & & Ricinus communis Linn. & Andi & Euphorbiaceae & Tree & Root, seed, leaves \\
\hline \multirow[t]{2}{*}{17} & \multirow[t]{2}{*}{$\begin{array}{l}\text { Irregular } \\
\text { menses }\end{array}$} & Wooodfordia fruticosa Salisb. & Dhavai & Lythraceae & Shrub & $\begin{array}{l}\text { Flower, stem, } \\
\text { bark }\end{array}$ \\
\hline & & Hibiscus rosa-sinensis Linn. & Gudhal & Malvaceae & Shrub & Flower, leaf \\
\hline \multirow[t]{2}{*}{18} & \multirow[t]{2}{*}{ Itching } & Plumbago zeylanica Linn. & Chitawari, Chitrak & Plumbaginaceae & Shrub & $\begin{array}{l}\text { Flower, leaves, } \\
\text { root }\end{array}$ \\
\hline & & Vitex negundo Linn. & Nirgundi & Verbenaceae & Shrub & Root, leaves \\
\hline \multirow[t]{11}{*}{19} & \multirow[t]{11}{*}{ Jaundice } & Raphanus sativus Linn. & Mooli & Brassicaceae & Herb & Leaves \\
\hline & & Cuscuta reflexa Roxb. & Amarbel & Convolvulaceae & Climber & Whole plant \\
\hline & & Phyllanthus niruri Linn. & Bhuiaonla & Euphorbiaceae & Herb & Whole plant \\
\hline & & Crotalaria sericea Retz. & Bansan & Leguminosae & Shrub & Whole plant \\
\hline & & Lawsonia alba Linn. & Mahendi & Lythraceae & Shrub & Leaves \\
\hline & & Melia azadirach Linn. & Mahaneem & Meliaceae & Tree & Bark, seed \\
\hline & & Achyranthes aspera Linn. & Chirchita & Amaranthaceae & Herb & Whole plant \\
\hline & & Buchanania lanzan Roxb. & Char & Anacardiaceae & Tree & Bark, fruit \\
\hline & & Terminalia arjuna Roxb. & Kahava & Combretaceae & Tree & Bark \\
\hline & & Tephrosia purpurea Pers. & Sarponkha & Asteraceae & Herb & $\begin{array}{l}\text { Leaves, whole } \\
\text { plant }\end{array}$ \\
\hline & & Madhuca latifolia Roxb. & Mahua & Sapotaceae & Tree & Bark, flower \\
\hline \multirow[t]{4}{*}{20} & \multirow{4}{*}{ Joint Pain } & Asparagus racemosus Wild. & Chedavari & Liliaceae & Climber & Tuber \\
\hline & & Vitex negundo Linn. & Nirgundi & Verbenaceae & Herb & Root leaves \\
\hline & & Pongamia pinnata (Linn.) & Karanji & Leguminosae & Tree & Seed, bark \\
\hline & & Costus speciosus Retz. & Keo-kand & Costaceae & Herb & Rhizome \\
\hline \multirow[t]{2}{*}{21} & \multirow[t]{2}{*}{ Kidney stone } & Boerhaavia diffusa Linn. & Pathribaji & Nyctaginaceae & Herb & Root \\
\hline & & Mycrotyloma uniflorum Lam. & Kulthi & Leguminosae & Climber & Whole pant, seed \\
\hline \multirow[t]{3}{*}{22} & \multirow[t]{3}{*}{ Leucorrhoea } & Butea monosperma Lam. & Palas & Leguminaceae & Tree & Flower, root bark \\
\hline & & Punica granatum Linn. & Anar & Lythraceae & Shrub & Flower \\
\hline & & Smilax macrophylla Roxb. & Ramdatoon & Liliaceae & Climber & Leaves, stem \\
\hline \multirow[t]{3}{*}{23} & \multirow[t]{3}{*}{ Malaria } & Andrographis paniculata Burm.f. & Bhuineem & Acanthaceae & Herb & Whole plant \\
\hline & & Tinospora cordifolia Willd. & Giloy & Menispermaceae & Shrub & Stem, stem bark \\
\hline & & Azadiricta indica A.Juss & Leem & Meliaceae & Tree & Bark, leaves \\
\hline \multirow[t]{2}{*}{24} & Male & Alangium salviifolium (L. f) & Thelkajari & Alangiaceae & Herb & Whole plant \\
\hline & impotency & Peucedanum agpurense C.B.Clarke. & Tejraj & Apiaceae & Herb & Whole plant \\
\hline 25 & Milk secretion & Hemidesmus indicus Linn. & Anantmool & Asclepiadaceae & Shrub & Root, leaves, stem \\
\hline & & Asparagus racemosus Wild. & Satawri & Liliaceae & Climber & Root \\
\hline & & Euphorbia hirta L. & Doodhi & Euphorbiaceae & Herb & Whole plant \\
\hline 26 & $\begin{array}{l}\text { Onset of } \\
\text { pregnancy }\end{array}$ & Acorus calamus Linn. & Bach & Araceae & Herb & Root \\
\hline 27 & Painful menses & Aegle marmelos (Linn.) Corr. & Bel & Rutaceae & Tree & Fruit pulp, leaves \\
\hline & $\begin{array}{l}\text { and Excessive } \\
\text { blood }\end{array}$ & Asparagus racemosus Wild. & Satavari & Liliaceae & Climber & Root \\
\hline & discharge & Gloriosa superba Linn. & Jhagrinphul & Liliaceae & Climber & Root, leaves \\
\hline 28 & Paralysis & Spilanthes oleracea Linn. & Akarkara & Asteraceae & Herb & Whole plant \\
\hline & & Bauhinia retusa Roxb. & Sehra & Leguminosae & Tree & Flower, bark \\
\hline & & Albizzia lebbek Benth. & Siris & Leguminosae & Tree & Fruit, stem bark \\
\hline $29 \mathrm{P}$ & & Wendlandia exserta D.C. & Tilai & Rubiaceae & Tree & $\begin{array}{l}\text { Root and stem } \\
\text { bark }\end{array}$ \\
\hline & & Ficus benghalensis Linn. & Bargad & Moraceae & Tree & Tree, fruit \\
\hline & & Butea monosperma Lam. & Palas & Leguminosae & Tree & Flower, bark \\
\hline & & Lannea grandis Dennst Engler. & Modga & Anacardiaceae & Tree & Bark \\
\hline & & Gardenia turgida, Roxb. & Fatera & Rubiaceae & Tree & Bark, flower \\
\hline & & Amorphophallus paeonifolius Dennst. & Zimikanda & Araceae & Herb & Tuber \\
\hline
\end{tabular}




\begin{tabular}{|c|c|c|c|c|c|c|}
\hline $\begin{array}{l}\text { S. } \\
\text { No. }\end{array}$ & $\begin{array}{l}\text { Name of } \\
\text { disease/ } \\
\text { ailment }\end{array}$ & Botanical name of the plant & $\begin{array}{l}\text { Vernacular name of } \\
\text { the plant }\end{array}$ & Family & Habit & Plant part used \\
\hline \multirow[t]{2}{*}{30} & \multirow{2}{*}{$\begin{array}{l}\text { Respiratory } \\
\text { disorder } \\
\text { (Dama) }\end{array}$} & Emblica officinalis Gaertn. & Aonla & Euphorbiaceae & Tree & Fruit pulp \\
\hline & & Cuscuta reflexa Roxb. & Amarbel & Convolvulaceae & Parasite & Whole plant \\
\hline 31 & Stomatch pain & Ficus religiosa Linn. & Pipal & Moraceae & Tree & Leaves, fruit \\
\hline 32 & Swelling & Vitex negundo Linn. & Nirgundi & Verbenaceae & Shrub & Leaves \\
\hline \multirow[t]{5}{*}{33} & \multirow[t]{5}{*}{ Snake bite } & Andrographis paniculata Burm.f. & Bhuileem & Acanthaceae & Herb & Whole plant \\
\hline & & Rauvolfia serpentina (L.) Benth. & Bhuikurva & Apocynaceae & Herb & Root, stem \\
\hline & & Abrus precatorius Linn. & Gunji & Leguminosae & Shrub & Seed, seed \\
\hline & & Vetiveria zizanioides (Linn.) Nash. & Khasgass & Gramineae & Herb & Leaves, root \\
\hline & & Gloriosa superba Linn. & Jhagrahin & Liliaceae & Herb & Flower, root \\
\hline \multirow[t]{2}{*}{34} & \multirow[t]{2}{*}{ Scorpion bite } & Rubia cordifolia Linn. & Manjita & Rubiaceae & Climber & Leaf \\
\hline & & Celastrus paniculata Willd. & Peng & Celastraceae & shrub & Seed, stem \\
\hline \multirow[t]{3}{*}{35} & \multirow[t]{3}{*}{ Sexual disease } & Peucedanumn agpurense, C.B.Clarke. & Tejraj & Apiaceae & Herb & Leaves \\
\hline & & Curculigo orchioides Gaertn. & Kalimusli & Hypoxidaceae & Herb & Root \\
\hline & & Chlorophytum tuberosum Baker. & $\begin{array}{l}\text { Kavrakanda / } \\
\text { Safedmusli }\end{array}$ & Sterculiaceae & Herb & Root \\
\hline \multirow[t]{3}{*}{36} & \multirow{3}{*}{$\begin{array}{l}\text { Tooth ache and } \\
\text { pyorrhea }\end{array}$} & Smilax macrophyla Roxb. & Ramdaton & Liliaceae & Climber & Stem, leaves \\
\hline & & Dioscorea daemona Roxb. & Koliyapad & Dioscoreaceae & Climber & Stem, leaves \\
\hline & & Tephrosia purpurea Pers. & Sarponkh & Leguminosae & Shrub & Root, bark \\
\hline 37 & Tuberculosis & Semicarpus anacardium Linn. & Bhelva & Anacardiaceae & Tree & Root, bark, seed \\
\hline \multirow[t]{2}{*}{38} & \multirow[t]{2}{*}{ Weakness } & Costus speciosus Retz. & Keo-kand & Costaceae & Herb & Root \\
\hline & & Asparagus racemosus Wild. & Satavari & Liliaceae & Climber & Root \\
\hline \multirow[t]{3}{*}{39} & \multirow[t]{3}{*}{ Worms } & Calotropis procera Alt. & Madar & Asclepiadaceae & Shrub & Leaves, root \\
\hline & & Holarrhena antidysenterica Well & Kurai & Apocynaceae & Tree & Seed, bark, leaves \\
\hline & & Mucuna pruriens Baker non,D.C & Kevanch & Leguminosae & Climber & Seeds, leaves \\
\hline
\end{tabular}

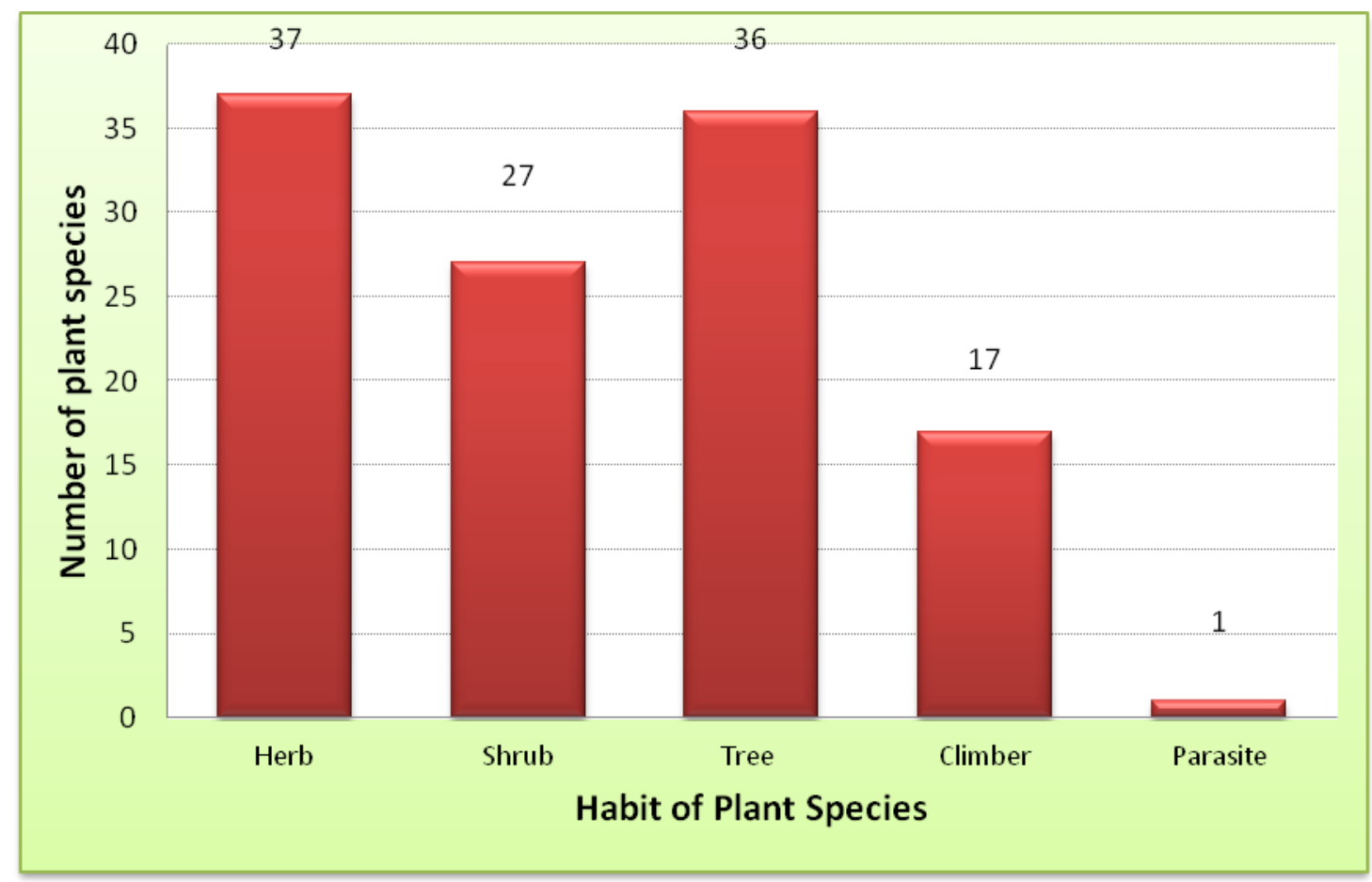

Fig. 1: Habit of plants used by the tribals of Bastar for health security.

Maximum number of plants used as a medicine by tribals belongs to family Liliaceae. There were eleven plants found to be used for jaundice, seven for piles, five each for dysentery and snake bite, four plants each for joint pain ear ach, cough, cold, cuts and wounds, three plants each for diabetes, malaria, and milk secretion. paralysis, toothache worms and two plants each for fracture, body ach, chest pain, male impotency, weakness, respiratory diseases, eczema (Bemchi), etching, scorpion bite while one plant each was noted for diseases like tuberculosis 
swelling, stomach pain, white discharge, weakness, easy delivery, eye problem, and kidney stone. Roots were found to be used use for curing body ache, eye problem, cuts and wounds, dysentery, ear ache, epilepsy, easy delivery, fever, head-ache, hydrocoel, itching, kidney stone, milk secretion, onset of pregnancy, stem for dysentery, fracture, rhizomes for joint pain and dysentery. More than one plants or combination of two or three plants were also found to be used by the tribals against various diseases to provide health security (Table 1).

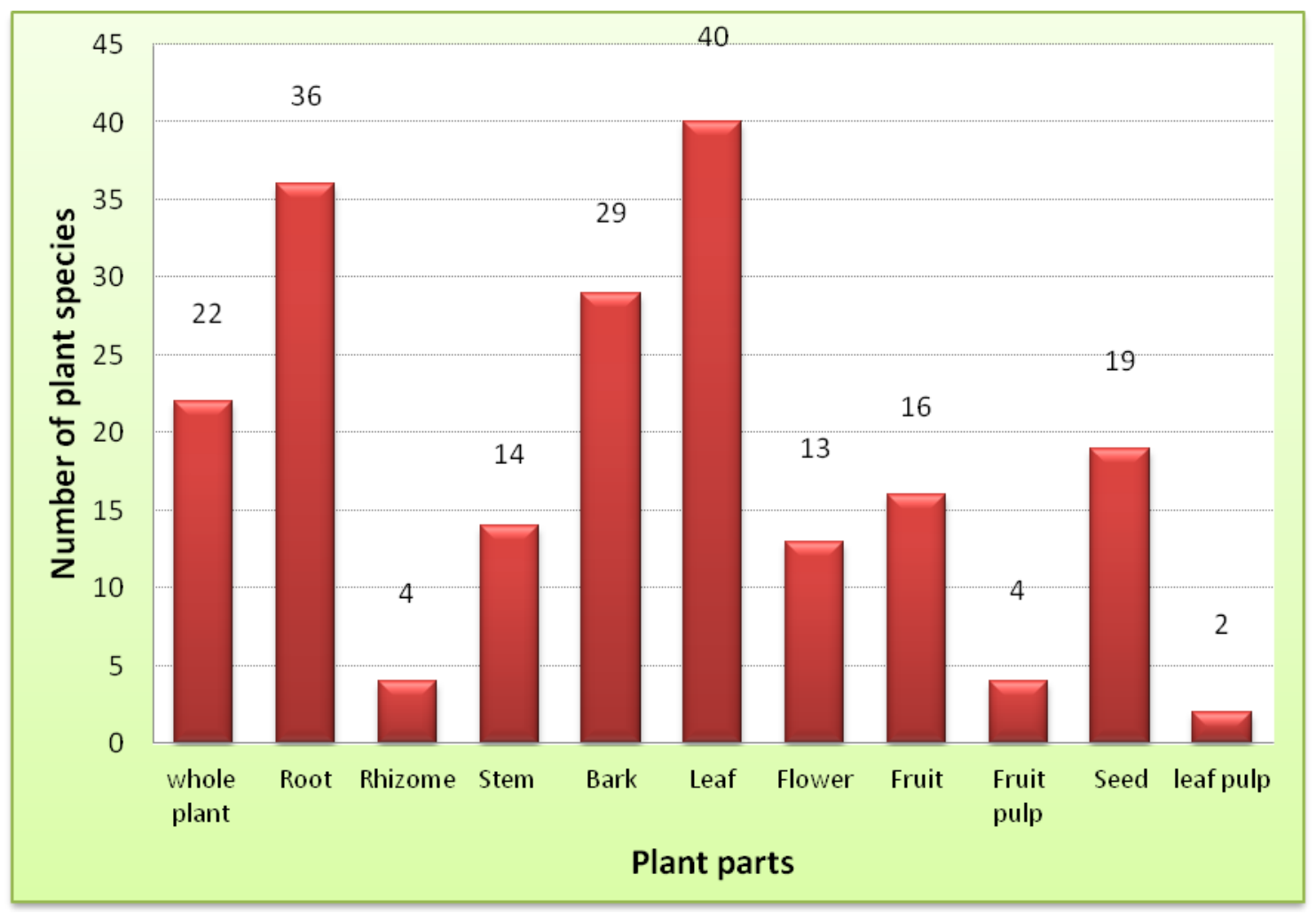

Fig. 2: Plant parts used by the tribals of Bastar for health security.

\section{Discussion}

The documentation of drug preparation confirmed that 118 plants individually or in combination of two or three were found to treat 39 diseases prevalent in Bastar district, during the present study (Lalramnghinghlova and Jha (1998) described more the 200 ethnomedicinal plant for their efficacy to cure diseases in Mizoram. Folk use of 128 plants at Madi valley of Chitwan district, Nepal was studied by Bishokarma et al. (2002), while in district Bastar 115 medicinal plants of health security was found to be used by the tribals. Kumar et al. (2007) and Biswas et al. (2003) reported that about 163 species of plants were used as wound healing plants in Indian system of medicine such as Ayurveda, Siddha, Unani and folk medicine. Of these only four plants like Aloe vera, Semicarpus anacardium, Abutilon indicum and Mucuna pruriens were found to be used by tribals of Bastar in wound healing. The tribal people of western Madhya Pradesh of India were found to use 13 plants for the treatment of jaundice (Samvatsar and Diwanji, 2000), while 11 plants were found to be used by the tribals of Bastar. The leaves of the plant Phyllanthus niruri is combined with white goat milk and taken in empty stomach in three doses for effective treatment of Jaundice and liver diseases and also enhances the appetite (Sankaranarayanan, 2008) similar reporting's were made during the present study in Bastar. Sometimes patient cannot open his /her mouth, the extract of plant is administered through nostril or eyes or applied liberally to the head (Anandan and Veluchamy, 1986; Anuradha et al., 1986). Majority of young generation do not know many plants and their medicinal values. Only few younger are following the medicinal practices and traditional knowledge in Nepal (Joshi and Edington, 1990; Shrestha and Dhillion, 2003). Similar condition was reported in the Bastar (Srivastava et al., 1999). Information that is related to women health problems viz., urinary infections, bleeding and pregnancy are difficult to acquire and treat. Such curative information is kept with secret, with the belief that the medicines would lose their effectiveness if revealed to other people (Bhat 
and Jacobs, 1995). Present study revealed such type of situation in district Bastar, therefore scientific cultivation, conservation and sustainable use of plant species by ethnic communities would be highly advantageous for socio economic growth, in conservation of rare and endangered plants species and the indigenous knowledge for the future generations.

The drug preparation methods were very old and traditional. Most of the drugs were found to be prepared either by making fine powder in pastel and mortal or paste or decoction or extract from plants were noted to be use directly. In some of the drugs it was noted that they mix other ingredients like honey, milk, curd, ghee, butter milk, jaggery, sugar, molasses, camphor, oil, etc. and their use of similar ingredients in administration of ethnomedicine (Sudhakar Reddy et al., 2008). In view of the importance of traditional medicine which provides health services to $75-80 \%$ of the world population, increased demand of herbal drugs by the pharmceauticals and depleting natural plant resources, it is high time to document the medicinal utility of less known plants available in remote areas of the country (Zaidi and Crow, 2005). In this way documentation of this vanishing tribal knowledge is worthful.

\section{Conflict of interest statement}

Authors declare that they have no conflict of interest.

\section{References}

Anandan, T., Veluchamy, G., 1986. Folk medical claims from Tamilnadu North Acrcot district. Bull. Med. Ethnopharmacol. Botanical Res. 73, 99-109.

Anuradha, U., Kumbhojkar, M. S., Vartak, V. D., 1986. Observations on wild plants used in folk medicine in the rural areas of the Kolhapur district. Ancient Sci. Life. 6, 119-121.

Bhat, R.B., Jacobs, T. V., 1995. Traditional herbal medicine in Transkei. J. Ethnopharmacol. 48, 7-12.

Bishokarma, B.K., Kinsey, C.K., Dongal, D.R., Chaudhary, P., 2002. Folk of plant resource at Madi valley of Chitwan district Nepal. Banko Janakari. 15(2), 28-33.

Biswas, S., Jain, S.S., Pal, M., 2003. Research needs and priorities for conservation of Indian medicinal flora. Indian For. 129(1), 85-92.
Jain, S.K., 1987. Ethnobotany-its scope and various sub disciplines. In: Manual of Ethnobotany (Ed.: Jain, S.K.). Scientific Publishers, Jodhpur. pp.1-11.

Jain, S.K., 1988. Detailed Proforma for Field Work in Ethnobotany. Ind. Training Course I Ethnobotany. 10-18 March 1988, Lucknow. 16p.

Jain, S.P., Singh, S.C., 1997. An Ethnomedico-Botanical Survey of Ambikapur District, M.P. Scientific Publishers, Jodhpur. pp.83-91.

Joshi, A.R., Edington, J.M., 1990. The use of medicinal plants by two village communities in the central Development Region of Nepal. Econ. Bot. 44, 71-83.

Kumar, B., Vijayakumar, M., Govindarajan, R., Pushpangadan, P., 2007. Ethnopharmacologial approaches to wound healing Exploring medicinal plants of India. J. Ethnopharmocol. 114, 103-113.

Lalramnghinghlova, H., Jha, L.K., 1998. Ethnomedicinal plants among the hill tribes of Mizoram. In: Prospects of Medicinal Plants (Eds: Gautam, P.L., Raina, R., Shrivastava, U., Raychaudhari, S.P., Singh, B. B.). Indian Society of Plant Genetic Resources, New Delhi. pp.67-86.

Masih, S.K., 1990. Ethno Botanical Studies in Tribal Areas of Bastar and Jabalpur. Ph.D. Thesis, Rani Durgawati University, Jabalpur (M.P.), India.

Roy, G.P., 1989. Tribals and Ethnobotany of Abujh-Marh Reserve area of Bastardistt. Problem of Wasteland and Forest Ecology. (Ed.: Promod Singh). Ashish Publishing House, New Delhi. pp.328-338.

Samvastsar, S., Diwanji, V.B., 2000. Plants sources for the treatment of jaundice in the tribals of western Madhya Pradesh of India. J. Ethnopharmacol. 73, 313-316.

Sankaranarayanan, S., 2008. Medical Taxonomy of Angiosperms: Recent Trends in Medicinal Uses and Chemical Constituents. $1^{\text {st }}$ Edn. Harishi Publication, India. pp.741-742.

Shrestha, P. M., Dhillion, S. S., 2003. Medicinal plant diversity and use in the highlands of Dolakha district, Nepal. J. Ethnopharmacol. 86, 81-96.

Shultes, R. E., Reis, S. Von. (Eds.), 1995. Ethnobotany: Evolution of a Discipline. Chapman and Hall, London.

Srivastava, J.L., Jain, S., Duvey, A., 1999. Ethno-medicine for anti-fertility used by the tribals in Bastar district of Madhya Pradesh. J. Econ. Taxon. Bot. 23(2), 297-300.

Sudhakar Reddy, C., Gopal Krishna. P., Raju, V.S., 2008. Phytotherapy at rural communities: A case study from the Gonds of Warangal district, Andhra Pradesh, India. Res. J. Bot. 3, 97-102.

Zaidi, M. A., Crow, S. A., 2005. Biologically active traditional medicinal herbs from Balochistan, Pakistan. J. Ethnopharmacol. 96, 331-334.

\section{How to cite this article:}

Sinha, M. K., Kanungo, V. K., Naik, M. L., 2016. Ethnobotany in relation to health security in district Bastar of Chhattisgarh State. Int. J. Curr. Res. Biosci. Plant Biol. 3(5), 120-126.

doi: http://dx.doi.org/10.20546/ijcrbp.2016.305.019 